\title{
Emiliana Konopka
}

Independent scholar

\section{Carl i Karin Larsson - twórcy szwedzkiego „domu idealnego”?}

\author{
Carl and Karin Larsson - Creators of the Swedish "Ideal Home"?
}

In 1888, two Swedish painters, Carl Larsson and Karin Larsson, moved to the mansion Lilla Hyttnäs in Sundborn (Dalarna, Sweden). This summer house became an ideal place for a big family with eight children, but was also a complex work of art which astonishes by its fantasy and uniqueness even today. These radiant rooms full of joy and love were depicted by Carl in his watercolours but can be visited in the museum founded after the death of the householders.

The Larssons' style was an inspiration for Scandinavian interior design and built an image of the "ideal home", mostly by illustrated albums with commentaries by Carl. By analyzing the story of the house, with its various inspirations and ideas, some links to contemporary Swedish furniture companies and the Social Democrats' concept of Folkhem met and lagom are given.

Key words: Carl Larsson, ideal home, Swedish interior style, welfare state

Słowa klucze: Carl Larsson, dom idealny, szwedzki styl urządzania wnętrz, państwo opiekuńcze

Postanowiłem sobie, iż Karin i nasze dzieci muszą zaznać szczęścia i bezpieczeństwa, dlatego też starałem się, by szczęście i bezpieczeństwo emanowały ze wszystkich moich obrazów, które przedstawiają nasz dom i rodzinę.

Carl Larsson, Ett Hem, 1899

Barwne akwarele szwedzkiego malarza Carla Larssona (1853-1919), przedstawiające życie całej rodziny Larssonów w przytulnie urządzonych wnętrzach, stanowią jedne z najpopularniejszych i najchętniej reprodukowanych przykładów szwedzkiego malarstwa. Kluczem do zrozumienia tego fenomenu jest Lilla Hyttnäs, rodzinny dom Larssonów znajdujący się do dzisiaj w Sundborn nieopodal Falun, w sercu szwedzkiej Dalarny. Budynek ten Carl nie tylko portretował, ale przede 
wszystkim współtworzył wraz ze swoją małżonką, Karin Bergöö (1859-1928). Posiadłość, którą w niemal niezmienionym stanie można zwiedzać do dziś, zachwyca połączeniem pomysłowej architektury, estetycznych dekoracji i życia w harmonii z naturą. Rozwiązania zaproponowane przez parę artystów na przełomie XIX i XX wieku wynikały z potrzeby stworzenia przestrzeni ładnej i wygodnej, odpowiadającej „człowiekowi nowoczesnemu”, a adresowane były do szwedzkiego mieszczaństwa. Jednocześnie wynikały $\mathrm{z}$ dwóch wiodących nurtów w sztuce szwedzkiej tego okresu: regionalizmu, czyli czerpania inspiracji z lokalnej sztuki ludowej, a nawet opierania wyobrażenia o tym, co szwedzkie, na tradycjach zachowanych na prowincji (w tym przypadku Dalarna), oraz tzw. „unarodowionego romantyzmu" (szw. nationalromantik), wyrażanego w malarstwie historycznym i licznych odniesieniach do wspólnej przeszłości Szwedów (Ciesielski 2016: 165-166). Mimo to wykreowany przez artystów „dom idealny” stał się inspiracją dla użytkowników na całym świecie, był wzorem nie tylko w sposobie urządzania mieszczańskiego wnętrza, ale również kreowania rodzinnej atmosfery, tworzenia domu jako przestrzeni przyjaznej wszystkim jego mieszkańcom.

Choć styl Lilla Hyttnäs nie powstał w artystyczno-kulturowej próżni, jest on fenomenem na skalę światową (Parissien, red., 2010: 233), a jego oryginalność i urok doceniały zagraniczne media jeszcze za życia artysty. Ilustracjami Szweda zachwycał się na polskim gruncie Jan Malisz, fotografik z Galicji, który wymieniał listy z artystą i marzył o złożeniu wizyty w Sundborn (Wisiecka 2015). Do popularyzacji twórczości Carla Larssona w Europie przyczyniły się przede wszystkim niemieckojęzyczne wydania jego albumów oraz powielanie wzorników i pomysłów takiego sposobu urządzania wnętrz w prasie specjalistycznej. Być może w modelu Lilla Hyttnäs upatrywano kontynuację myśli biedermeierowskiej ${ }^{1}$, czyli tworzenia mieszczańskiego domu opartego na wygodnych, ale estetycznych rozwiązaniach. Cytowane w motto pracy szczęście i bezpieczeństwo domowego ogniska stanowiły wówczas ideał, do którego dążyli przedstawiciele europejskiego mieszczaństwa połowy XIX wieku.

Sama więc kreacja otoczenia przystępnego do życia mieszczańskiej rodziny nie jest novum ani w Europie, ani w samej Szwecji. Proponowane przez Larssonów zmiany wpisywały się w powolny, trwający od połowy XIX wieku, proces przemian zachodzących $\mathrm{w}$ społeczeństwie oskariańskim². Jak podają Jonas Frykman i Orvar Löfgren, „W kulturze mieszczańskiej dom staje się przedsięwzięciem nie

\footnotetext{
$1 \quad$ Styl w kulturze, przede wszystkim odnoszący się do wystroju wnętrz, popularny w środowiskach mieszczańskich Europy Środkowej w okresie 1815-1848. Kładziono nacisk na prostotę i wygodę mebli, a także dostosowanie sprzętów do ich użyteczności.

2 Chodzi o społeczeństwo szwedzkie za panowania Oskara II z dynastii Bernadotte (18721907). O „dziedzictwie oskariańskim” piszą: Jonas Frykman, Orvar Löfgren oraz Waldemar Kopczyński (zob. Kopczyński 2013: 49-62).
} 
tylko praktycznym, ale także moralnym” (Frykman, Löfgren 2007: 128). Z jednej strony dom, będący wizytówką rodziny, łączył w sobie funkcje miejsca publicznego, do którego zapraszano gości i którym chwalono się w towarzystwie, ale też miejsca prywatnego, gdzie każdy domownik dysponował przypisanym sobie kątem, w którym mógł odpocząć. Z drugiej strony na przełomie wieków coraz częściej dyskutowano o domu przepełnionym szczęściem i miłością, także jako o miejscu beztroskiego dzieciństwa ${ }^{3}$ i niezmąconego spokoju.

Podobnie nie jest zasługą Larssonów propagowanie samodzielnego wykonywania mebli czy własnych dekoracji domowych. W Szwecji od 1845 roku funkcjonował Slöjdföreningen, związek propagujący robótki ręczne i rzemieślnictwo ${ }^{4}$ wśród młodzieży szkolnej i gospodyń domowych. O wiele szerszym echem odbił się natomiast w Europie program Williama Morrisa i założenia Arts \& Crafts, podkreślające piękno i artystyczną wartość przedmiotów wykonanych ręcznie, wedle zasad średniowiecznego rzemiosła, nie zaś w wyniku produkcji przemysłowej. Jak twierdzi jednak Per I. Gedin, biograf Carla Larssona, inspiracją dla Lilla Hyttnäs były tak slöjdy, jak twórczość Morrisa, ale równie istotne stały się trendy zaczerpnięte z ówczesnych czasopism angielskich (Gedin 2011: 343).

W tekście tym pragnę zaprezentować Lilla Hyttnäs jako przykład domu idealnego. „Idealny” to według Słownika języka polskiego: „odznaczający się najwyższą jakością, samymi zaletami, dokładnie czemuś odpowiadający; doskonały, znakomity, bezbłędny, wzorcowy” (1978: 766). Poprzez „dom idealny” rozumiem przestrzeń łączącą w sobie cechy „wnętrza idealnego”, a więc dostosowanego do potrzeb i preferencji jego użytkowników, zaprojektowanego w sposób doskonały, wzorcowy, ale też odznaczający się najwyższą jakością, oraz zacisza domowego, będącego ostoją intymności i prywatności, dającego szczęście i bezpieczeństwo. Koncept „domu idealnego” nie będzie tutaj jednak postrzegany w kategoriach utopijnego projektu, nie staram się także dowieść, że mieszkańcy Lilla Hyttnäs byli faktycznie szczęśliwą i kochającą się rodziną. Istotą mojego wywodu jest skupienie się na realnym domu wykreowanym na ideał, będący w głównej mierze produktem, jaki przedstawił na swoich akwarelach Carl Larsson. Słynny album noszący tytuł Ett Hem, czyli po prostu „dom”, stanowił bowiem nie tylko wizytówkę domu jako kreacji artystów, ale też miejsca, w którym panowała sielankowa atmosfera. Wydawać by się mogło, że poszukiwany w Lilla Hyttnäs genius loci przejawia się przede wszystkim w geniuszu samego artysty, a wizja domu jako „idealnego”

\footnotetext{
3 Szczególnie popularne stały się pisma Ellen Key, prekursorki ruchu reformy pedagogicznej, postulującej dostosowanie standardów życia do najmłodszych. Obraz szczęśliwego, idealnego dzieciństwa dopełniały również współczesne ilustracje książek dla dzieci, autorstwa między innymi Elsy Beskow.

4 W roku 1976 Związek zmienił nazwę na Svensk Form i, mimo pewnych przekształceń, funkcjonuje do dziś.
} 
została wykreowana przez niego samego i powielona przez współczesnych komentatorów i późniejszych badaczy.

\section{Miejsce. Dzieje Lilla Hyttnäs i kreacja wnętrza idealnego}

Dom, o którym mowa, znajduje się w miejscowości Sundborn położonej około $13 \mathrm{~km}$ na północny wschód od Falun, administracyjnej stolicy regionu Dalarna. Lilla Hyttnäs (szw. mała chatka), została wybudowana w 1837 roku i swą nazwę zawdzięcza położeniu obok większej wilii. Oryginalnie chatka ta stanowiła przykład härbre (szw. spichlerz, magazyn), drewnianej budowli z kamiennym fundamentem używanej głównie do przechowywania żywności. W Szwecji XIX wieku takie mniejsze budynki położone w ogrodzie zaczęły z czasem funkcjonować jako domki letniskowe, ale również można było mieszkać w nich na stałe. To tutaj urodził się i wychował Adolf Bergöö, ojciec Karin, który w 1888 roku podarował swój dom rodzinny młodej parze. Carl Larsson tak opisuje swoje pierwsze wrażenia dotyczące Lilla Hyttnäs: „Był to zwykły, brzydki i nic nie znaczący budynek, postawiony na głazie odrzuconym w kopalniach. [...] Wnętrze było nieskazitelne, meble proste, ale w starym stylu i solidne, należące niegdyś do rodziców [mojego teścia - E.K.], którzy mieszkali w pobliżu” (Larsson 1998)5 . Dzięki malowniczemu położeniu na samym łuku rzeki Sundborn chatka ta wydawała się malarzowi „małą idyllą skrojoną na miarę artysty” (Larsson 1998) ${ }^{6}$. Domek wraz z wyposażeniem stał się własnością Carla i Karin i początkowo wykorzystywany był przez młode małżeństwo z trójką dzieci jako domek letniskowy.

We wstępie do albumu Ett Hem, wydanym w 1899 roku, Carl pisze o radykalnych zmianach zewnętrza i wnętrza domu, które zaszły w ciągu kolejnych letnich pobytów Larssonów w Lilla Hyttnäs pomiędzy 1888 a 1898 rokiem. „Miało być dokładnie tak, jak ja chciałem, inaczej nie mógłbym tu być szczęśliwy, a moja dotychczasowa praca poszłaby na marne" (Larsson 1998)7. Według akwareli wykonywanych przez Carla oraz zachowanych fotografii można prześledzić najważniejsze przekształcenia bryły budynku i pomieszczeń, choć trudne pozostaje dokładne datowanie tych zmian. Na jednej z akwareli publikowanej w 1899 roku, ale powstałej najprawdopodobniej między 1890 a 1899 rokiem (ilustracja 1), Carl przedstawia

Por. „Det var en liten oansenlig, ful och intetsägande byggnad, liggande på ett slaggvarp. [...] Allt inomhus var rent och fint, möblerna voro af enklaste slag, men gammaldags och hållbara, arf efter föräldrarna, hvika bott på en egendom i närheten”. Jeśli nie zaznaczono inaczej, tłumaczeń z języka szwedzkiego dokonała autorka artykułu.

6 Por. „denna lilla idyll skulle passa en konstnär”.

7 Por. „Stugan måste jag ha såsom jag ville ha den, annars skulle jag vantrifvas i den och det skulle mitt arbete lida på”. 
budynek w stanie, w jakim został on pozostawiony przez Adolfa Bergöö i jego siostry. Na obrazie podkreślona jest charakterystyczna czerwień budynku, który zgodnie z tradycją barwiony został tzw. czerwienią faluńską (szw. faluröd), farbą pozyskiwaną z odpadów miedzi wydobywanej w lokalnej kopalni. Dwukondygnacjowa budowla, której wygląd potwierdzają fotografie z tego okresu, była dość zwarta, z głównym wejściem $\mathrm{w}$ znacznie wysuniętym przed lico ściany ryzalicie ${ }^{8}$, którego przedłużenie stanowił salon $\mathrm{z}$ wysokimi oknami, oraz niewielkim aneksem $\mathrm{z}$ osobnym wejściem i spadzistym dachem. Główny trzon budynku, przykryty dachówką, zwieńczony jest maszkaronem ${ }^{9}$ przypominającym smoki z wikińskich okręgów typu drakkar ${ }^{10}$. Natomiast na akwareli z 1909 roku zilustrowane są już efekty istotnej przebudowy, w której to nową pracownię, początkowo oddzielny budynek, połączono korytarzem z głównym domem, pozbywając się tym samym niższego aneksu i maszkarona, uzupełniając zaś parter o dodatkowe okno, a piętro - o balkon.

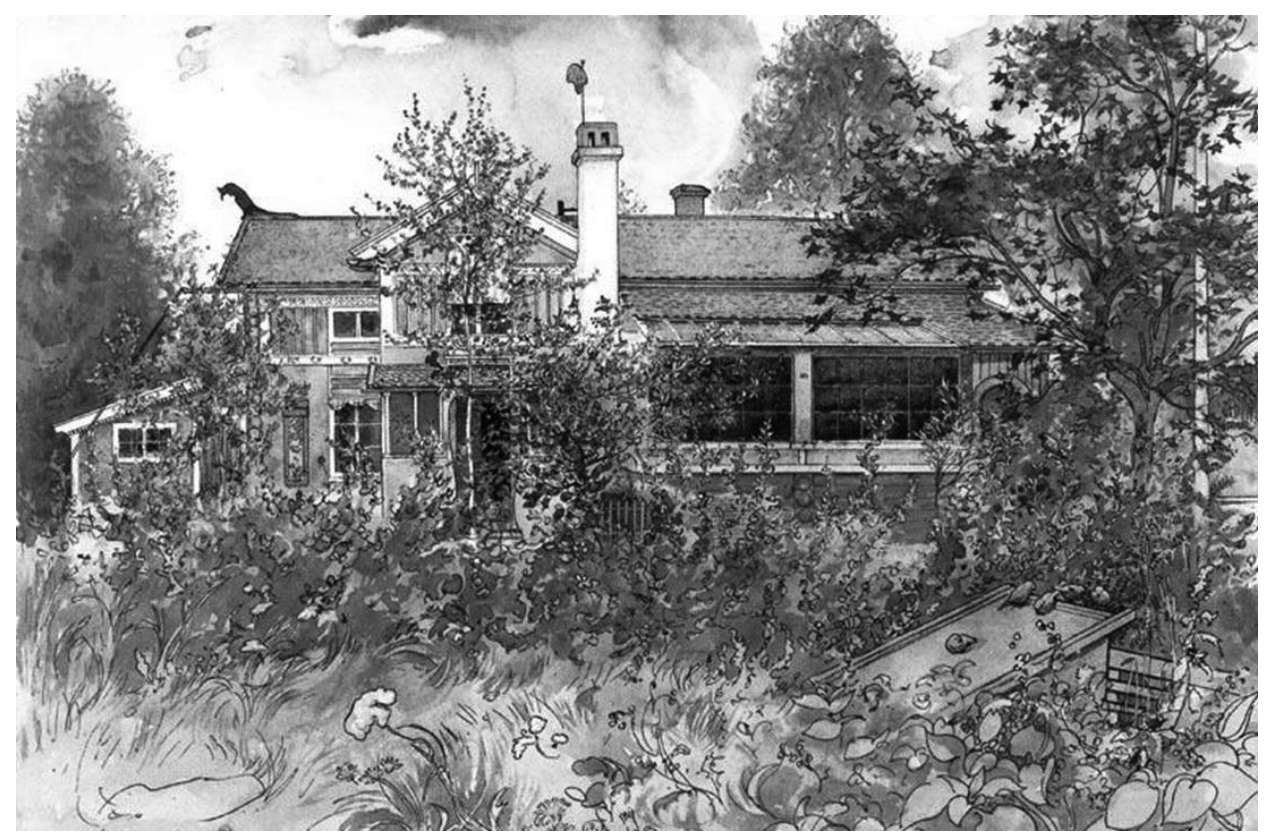

Ilustracja 1. C. Larsson, Chatka (szw. Stugan),

ok. 1895, akwarela na papierze $32 \times 43 \mathrm{~cm}$, Nationalmuseum, Sztokholm

Źródło: http://www.carllarsson.se/wp-content/uploads/2016/06/

Top_malning_05.jpg [dostęp: 12.09.2019].

8 Ryzalit - występ w bryle budynku, prowadzony od fundamentu aż po dach.

9 Maszkaron - rzeźbiarskie zwieńczenie architektoniczne w postaci stylizowanej głowy ludzkiej lub stworzenia fantastycznego.

10 Drakkar - rodzaj długiej łodzi wikińskiej, której cechą charakterystyczną było umieszczanie łbów smoczych na dziobie. 
W roku 1901 Larssonowie, posiadający już siedmioro dzieci, przeprowadzili się do domku na stałe, wówczas znacznie rozbudowanego i powiększonego w 1897 roku o sąsiadujące gospodarstwo Spadarfvet. Cała rodzina mieszkała tam bez przerw aż do śmierci obojga właścicieli, zaś ich potomstwo przekazało dom założonej w 1946 roku fundacji, której zadaniem miało być nie tyle utworzenie muzeum, co użytkowanie budynku jako domu otwartego dla zwiedzających; kontynuowano więc dawne rodzinne tradycje, używając wszystkich zgromadzonych $\mathrm{w}$ domu sprzętów i mebli. Z raportu Tiny Manoli i Nicoli Costarasa prezentującego przygotowania do wystawy „Carl and Karin Larsson: Creators of the Swedish Style” dla V \& A Museum w Londynie wynika, że jeszcze w 1997 roku goście „,iedzieli na krzesłach, spali w łóżkach i używali stołów, które miały być potem odpowiednio zabezpieczone jako obiekty muzealne dla potrzeb wystawy"11. Dzisiaj dom Larssonów, w niemal niezmienionej formie, otwarty jest dla zwiedzających każdego lata jako prywatne muzeum funkcjonujące pod oficjalną nazwą „Carl Larsson-gården”.

\section{Geniusze. Larssonowie jako kreatorzy}

Małżeństwo Larssonów nie było wyjątkowe na tle innych artystycznych par tamtych czasów. Carl Larson i Karin Bergöö poznali się w podparyskiej kolonii artystycznej Grez-sur-Loign, bardzo popularnej wśród skandynawskich artystów ostatniej dekady XIX wieku (Varnedoe 1988: 162). Wziąwszy ślub w 1883 roku, rok później wrócili do ojczystego kraju z pierwszą córką. Ostatecznie doczekali się ośmiorga dzieci: Suzanne, Ulf, Pontus, Lisbeth, Brita, Mats (zmarł po dwóch miesiącach życia w 1894 roku), Kersti i Esbjörn, i wspólnie stworzyli kochającą się i wspierającą rodzinę. Oboje otrzymali artystyczne wykształcenie: Carl studiował malarstwo na sztokholmskiej Akademii Sztuk Pięknych, a w roku 1877 wyjechał do Francji, gdzie zwrócił szczególną uwagę na technikę akwareli, natomiast Karin rozpoczęła naukę na Akademii w 1877 roku, a do Francji udała się od razu po ukończeniu studiów w 1882 roku.

Było to jednak małżeństwo niezwykłe z uwagi na panujące zwyczaje i reguły społeczne. Choć Lilla Hyttnäs kojarzona jest przede wszystkim z Carlem, małżonkowie mieli równy wkład w jej tworzenie. Zarówno mąż, jak i żona posiadali swoje pracownie i oboje w nich tworzyli. Nawet jeśli Carl pełnił tradycyjną rolę homo economicus, gdyż zajmował się sztuką zawodowo (za honorarium z malowideł ściennych dla Nationalmuseum w Sztokholmie rodzinę było stać na kupno Spadarfvet), a Karin przypadła funkcja pozostającej w domu femina do-

\footnotetext{
11 Por. „as we sat on the chairs, slept in the beds and used the table, which we will next see carefully installed as museum objects in our exhibition", za: Costaras, Manoli 1997.
} 
mestica $^{12}$, nie była ona tylko panią domu opiekującą się mężem i dziećmi, ale artystką nierezygnującą z tworzenia. Małżonkowie bardzo często się uzupełniali, również jeśli chodziło o wykonywanie dekoracji poszczególnych pomieszczeń domu. Carl, wnuk stolarza, projektował i przerabiał meble oraz wykonywał fryzy i malowidła na ścianach czy drzwiach, z kolei Karin tkała i szyła własnego projektu dywany, pokrycia mebli, obrusy, zasłony i ubrania, w tym słynny Karinförkläde, fartuch kuchenny $\mathrm{z}$ falbanami i wiązaniem $\mathrm{z}$ tyłu. Tworzyła także projekty mebli, jak w przypadku dziecięcych łóżek zrobionych ze starego pokrycia dachu albo fotela bujanego. Na akwareli Carla Pisanie listu z 1912 roku widoczny jest natomiast nowoczesny kwietnik projektu Karin.

Pomysłowość i współpraca przełożyła się jednak nie na pojedyncze prace dwóch niezależnych artystów, ale Gesamtkunstwerk, „dzieło totalne”, jakim był cały ich dom. Poszczególne wnętrza: jadalnia, kuchnia, salon, sypialnie oraz pracownie i gabinety dzieci stanowią jedną całość, ale każde z nich jest niepowtarzalne. We wszystkich pokojach widać jednak zamiłowanie właścicieli do łączenia różnych stylów, a przede wszystkim starego z nowym (Puvogel 1994: 13). We wnętrzach zachowano oryginalną drewnianą podłogę, a w jadalni także barwioną boazerię, ważnym elementem pierwotnego wyposażenia były meble gustawiańskie ${ }^{13}$ malowane na biało. Pozostawiono również oryginalne gomółkowe okna, które skutecznie ograniczały ilość wpadającego światła do wnętrz takich jak sypialnia Carla, albo okna ze szprosami, dzięki którym światło wypełniało całą przestrzeń salonu. Gospodarze chętnie przerabiali te pierwotne elementy, na przykład kredens w jadalni został pomalowany $\mathrm{w}$ kwieciste wzory, $\mathrm{z}$ kolei $\mathrm{w}$ okna wprawiano witraże inspirowane sztuką gotycką czy drzeworytami japońskimi. W salonie i sypialni, a szczególnie w obiciach mebli czy dywanach projektów Karin, widoczna jest inspiracja folklorem, szczególnie lokalnym, pochodzącym z regionu Dalarna, jak i zainteresowania nowymi rozwiązaniami, na przykład w przypadku obić w biało-niebieskie pasy. Nawiązania do sztuki ludowej widoczne są także w malowidłach naściennych Carla; w swojej pracowni wykonał fryz ze scenami życia Chrystusa, inspirując się dziewiętnastowieczną sztuką regionu Halland, z kolei drzwi do jadalni czy kuchni udekorowane są bordiurami z cytatami z Pisma Świętego czy szwedzkimi lub francuskimi porzekadłami.

„Nowe” reprezentowały w domu Larssonów koncepty modernizujące życie codzienne, umożliwiające funkcjonalizm obecnych mebli oraz ład i porządek we

\footnotetext{
12 O tradycyjnym podziale na role: męża zarabiającego na rodzinę i żony doglądającej domu piszą Frykman, Löfgren 2007: 135.

13 Styl gustawiański - styl wnętrz za panowania Gustawa III (1746-1792) w Szwecji, inspirowany francuskim rokokiem. Charakteryzował się występowaniem przepierzeń, częściowo przysłanianymi oknami, niewielkimi meblami wykonywanymi z jasnego drewna lub malowanych na biało. Używano też tkanin i obić o prostych wzorach.
} 
wnętrzach. $\mathrm{Z}$ uwagi na ograniczenie przestrzeni zastosowano liczne rozwiązania pozwalające na zachowanie maksymalnej przestronności wnętrz: $w$ jadalni i kuchni zaprojektowano system półek na naczynia i wsporników do wieszania dzbanów, zaś drzwi pomiędzy tymi pokojami w razie potrzeby miały podtrzymywać rozkładany stół, który na co dzień stał oparty o ścianę, przysłonięty krzesłami (ilustracja 2). W samej kuchni zwraca uwagę także widoczna ilość wolnego miejsca, która pozwalała na swobodne wykonywanie podstawowych prac.

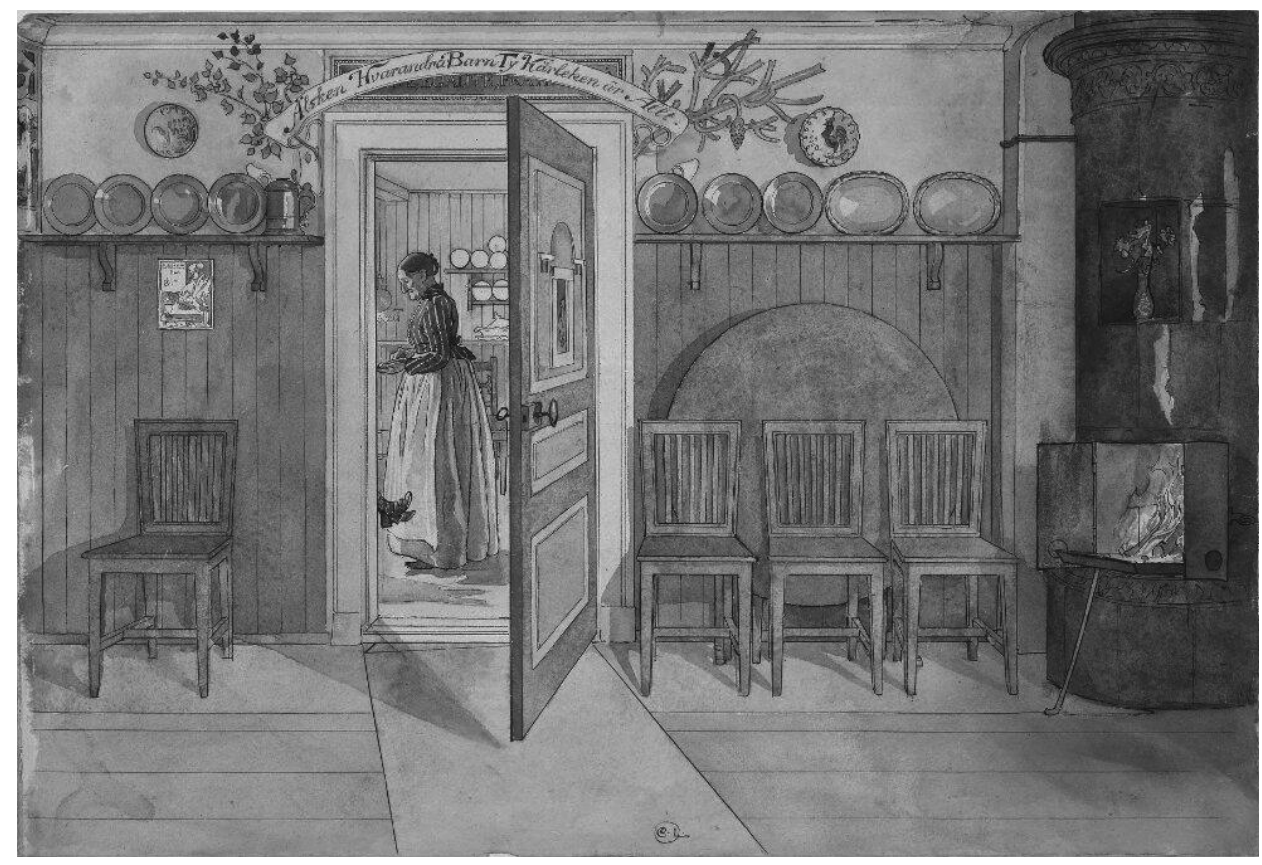

Ilustracja 2. C. Larsson, Stara Anna (szw. Gamla Anna),

między 1890 a 1899, akwarela na papierze $32 \times 43 \mathrm{~cm}$, Nationalmuseum, Sztokholm

Źródło: https://digitaltmuseum.se/021046503157/

gamla-anna-ur-ett-hem-26-akvareller [dostęp: 12.09.2019].

Odpowiednie wykorzystanie wolnej przestrzeni szło $\mathrm{w}$ parze $\mathrm{z}$ prostotą wnętrz i higieną. Posiadłość Lilla Hyttnäs była domem funkcjonalnym, ale też wygodnym i nowoczesnym: Larssonowie starali się o jak najszybsze doprowadzenie bieżącej wody czy elektryczności, a duże okna wpuszczające naturalne światło przez większość dnia oraz jasna kolorystyka mebli i ścian podkreślały czystość i przestronność. Biel nierzadko jest jednak przełamana intensywną kolorystyką obić czy kilimów, które wprowadzają ciepłą atmosferę, podobnie jak drewniane sufity i podłogi. 


\section{Geniusz miejsca: kreacja miejsca idealnego}

Ciepła atmosfera była nie tylko dziełem rodziców, ale także dzieci, od małego uczonych rękodzieła i drobnych prac domowych. Skoro dom był wspólnym dziełem, dostosowano go do potrzeb każdego domownika ${ }^{14}$ i tym samym każdy dorosły, dziecko, a nawet pies Kapo - mógł czuć się tu swobodnie i bezpiecznie. Obraz radosnej rodziny w domu przepełnionym szczęściem został zaprezentowany w akwarelach Carla. Już w Ett Hem Larsson zaprezentował czytelnikowi, pokój po pokoju, wnętrza, które udało się mu stworzyć wspólnie z Karin. Dwadzieścia cztery obrazy przedstawiają poszczególne pomieszczenia z podkreśleniem śmiałych rozwiązań oraz panującej w nich atmosfery. Dominuje w nich ciepła, pastelowa kolorystyka i delikatny, dwuwymiarowy rysunek, który przypomina styl baśniowych ilustracji. W rzeczywistości wnętrza te, przynajmniej obecnie, nie są aż tak rozświetlone jak na akwarelach Larssona, choć jasność i światło były jedną z innowacji, które Larssonowie wprowadzili do ówczesnej dekoracji wnętrz. Carl chętnie portretuje domowników w bardzo naturalnych sytuacjach. Stara Anna, kucharka i służąca, w ciszy i z namaszczeniem obiera rzepę, ale nie jest sama - przez drzwi kuchni dostrzec można także drobne stópki odziane w kolorowe pończochy. Z kolei w kącie salonu na krześle widać zniecierpliwionego Pontusa, który musi odsiedzieć karę za jakieś drobne przewinienie. Ten sam salon przedstawiony jest także $\mathrm{z}$ innej perspektywy - z perspektywy „leniwego zakątka”, gdzie każdy czuje się swobodnie, nawet psu pozwolono bezkarnie wylegiwać się na dywanie. Któryś z domowników zostawił pantofle, fajka taty opiera się o ławę, a koce na kanapie są nieposkładane (ilustracja 3). Wykorzystywanie salonu jako pokoju dziennego było czymś nowym w oskariańskiej obyczajowości; wedle zwyczaju salon był zarezerwowany dla gości lub podniosłych okazji, zaś Larssonowie dokonali „odczarowania” wnętrza i wypełnili go osobistymi drobiazgami: rycinami lub fotografiami osadzonymi w klasyczne ramy czy bujną roślinnością wspinającą się na ściany i sufit.

Beztroska, otwartość i gościnność nie były jednak tylko cechami zapisanymi farbą na czerpanym papierze. Nad drzwiami wejściowymi Carl umieścił wymalowany napis: „Bądź, mój drogi, pozdrowiony u Carla Larssona i jego żony” ${ }^{15}$, co miało dowodzić gościnności również w świecie rzeczywistym. Włoski dziennikarz Antonio Beltramelli, który dla "Corriere della Sera” opisał swoją wizytę u Larssonów w roku 1909, nadał domowi określenie „La Casa Gioconda”, porównując dom roztaczający jasność i uśmiech do Mona Lisy. „Nie czułem się jak obcy, ale

\footnotetext{
14 Por. „Each family member designed, constructed, and embellished the home according to his/her individual inclinations and capabilities” (Facos 1996: 82).

15 Por. „War välkommen kära du, till Carl Larsson och hans fru!”.
} 


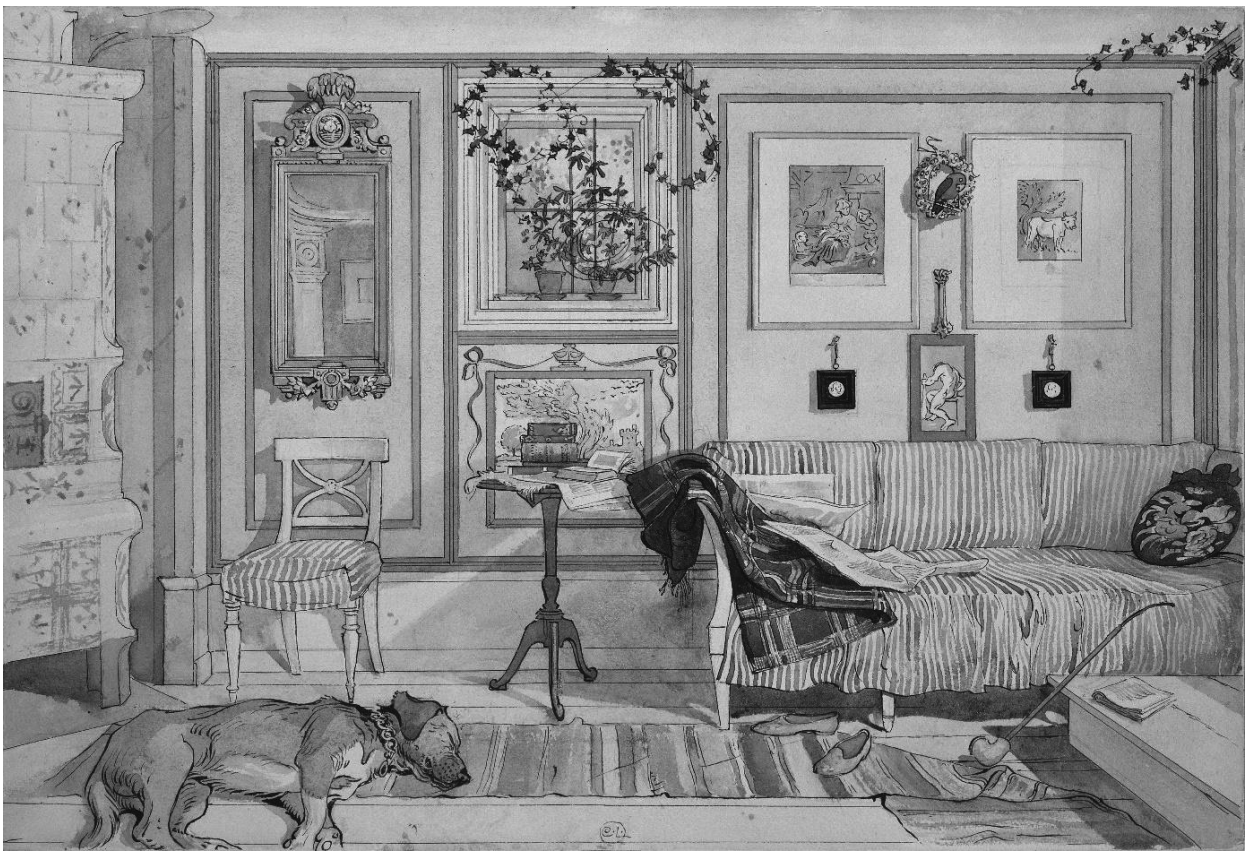

Ilustracja 3. C. Larsson, Leniwy zakątek (szw. Lathörnan), 1894, akwarela na papierze $32 \times 43 \mathrm{~cm}$, Nationalmuseum, Sztokholm

Źródło: https://upload.wikimedia.org/wikipedia/commons/ thumb/4/47/Carl_Larsson-Lath\%C3\%B6rnet.jpg/1280px-Carl_Larsson-Lath\%C3\% B6rnet.jpg [dostęp: 12.09.2019].

raczej jak dobry przyjaciel, który wraca po długiej nieobecności”" ${ }^{16}$, pisał. Z jego relacji, jak i wielu innych, wynika, że był to dom przepełniony miłością, a przedstawiona w akwarelach rodzinna idylla była prawdziwa. Larssonowie razem spędzali wszystkie najważniejsze uroczystości, takie jak urodziny czy imieniny, ale celebrowali również typowe tradycje szwedzkie czy święta religijne. Jednak receptą na sukces udanego życia rodzinnego był przede wszystkim wzajemny szacunek do pracy i siebie nawzajem. Larssonowie jako jedni z pierwszych zwrócili uwagę na rolę i potrzeby dziecka we wnętrzu, a także szanowali pomoc służby i robotników - choć sami wykonywali meble, korzystali też z pomocy wykwalifikowanych rzemieślników.

16 Por. „Non pare già che io sia uno straniero, ma un buon amico che ritorna dopo una lunga assenza" (Beltramelli 1907: 3). 


\section{Dom ludu? Elementy „ideału” Larssonów w Folkhemmet}

Wiele z pomysłów lansowanych przez Larssonów można wpisać w późniejszą ideę Folkhemmet $^{17}$ (szw. dom ludu), propagowaną przez socjaldemokratów od lat 30. XX wieku. Larssonowie nie dożyli czasów rozkwitu szwedzkiego państwa opiekuńczego, nie jest jednak pewne, czy Carl popierałby ich, bowiem kwestią sporną pozostają jego poglądy polityczne. Michelle Facos opisuje jego twórczość pod kątem wątków socjalistycznych (Facos 2011), Magdalena Wisiecka podkreśla natomiast różnicę w poglądach politycznych między Janem Maliszem a szwedzkim malarzem: „Jan Malisz był socjalistą, a C. Larsson zwolennikiem oświeconego absolutyzmu" (Wisiecka 2015). Wiadomo jednak, że artysta zmieniał swoje poglądy, ale $z$ wielu jego tekstów jasno wynika, że popierał demokratyzację sztuki i promowanie rozwiązań dostępnych dla całego społeczeństwa. Choć sam nie wywodził się z burżuazji (pochodził z niższych warstw), poprzez małżeństwo z Karin, a przede wszystkim dzięki randze artysty o międzynarodowej sławie, awansował społecznie i w latach Lilla Hyttnäs sam reprezentował bogate mieszczaństwo.

We wstępie do Ett Hem oraz tekstach do późniejszych publikacji zbiorów akwareli Carla Larssona, takich jak Larssons (1902) czy Spadarfvet (1906), autor sformułował swego rodzaju manifest, który miał charakteryzować styl Larssonów. Albumy z akwarelami miały także na celu promocję dekoracji wnętrz w łatwy, tani i funkcjonalny sposób. Chodziło o umożliwienie każdemu urządzenia domu nowoczesnego i ładnego, a przy tym skromnego „zakątka”, służącego do wygodnego życia, a nie na pokaz. Carl Larsson był świadom, że wraz z żoną dokonują reformy dekoracji wnętrz, co więcej, we wstępach zwracał się bezpośrednio do swojego czytelnika, nawiązując do inspirowania się proponowanymi rozwiązaniami dotyczącymi nie tylko sztuki, ale też stylu życia. Te swoiste „odezwy” kierowane były przede wszystkim do rodaków: „Więc, Szwedzie [...] stań się na powrót prosty i pełen godności, bądź raczej niezgrabny niż elegancki [...] niech twoje ręce rzeźbią lub malują twoje meble jak najpiękniej potrafią. Wtedy bowiem będziesz szczęśliwy z tego powodu, że jesteś sobą" ${ }^{18}$ i podkreślały wartość samodzielnego wykonywania przedmiotów do domu oraz wedle indywidualnego mniemania, bo osoby, które w nim mieszkają, mają czuć się swobodnie i szczęśliwie (ilustracja 4). Jak pisze Renate Puvogel (1994), sugestie Larssonów dotyczące urządzania domów wyprzedzały koncepcje „integralnego stylu życia”, który w przyszłości głosił na przykład Bauhaus.

17 O związku szwedzkiej socjaldemokracji z domem Larssonów pisała Facos (2011).

18 Por. „O, svensk [...] blif åter enkel och värdig, var hellre klumpig än elegant [...] samt låt din hand otvingad på ditt bohag skära ut eller måla de snirklar han vill och kan. Då skall du blifva lycklig i känslan af att vara dig själf” (Larsson 1899: 4). 


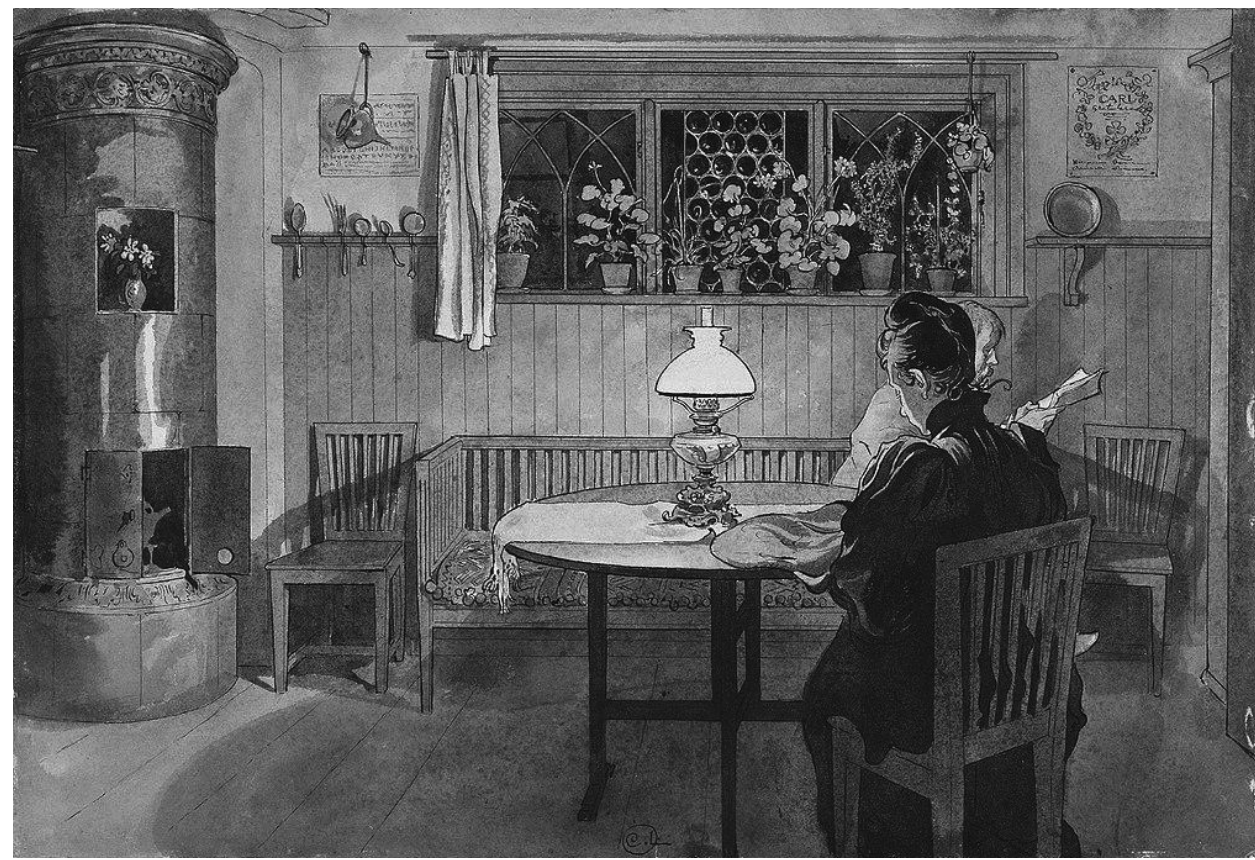

Ilustracja 4. C. Larsson, Kiedy dzieci pójda już spać (szw. När barnen har gått och lagt sig), 1895, akwarela na papierze, $32 \times 43 \mathrm{~cm}$, Nationalmuseum, Sztokholm

Źródło: https://upload.wikimedia.org/wikipedia/commons/ thumb/7/79/When_the_Children_have_Gone_to_Bed.jpg/ 1280px-When_the_Children_have_Gone_to_Bed.jpg [dostęp: 12.09.2019].

Jedni z twórców szwedzkiego państwa opiekuńczego Alva i Gunnar Myrdal ${ }^{19}$ potwierdzili wiele z przekonań artystów, takich jak konieczność wprowadzenia zasad higieny i estetyki w życie codzienne, ważną rolę rodziny i potomstwa, jak i ogólnie pojętej modernizacji i optymalizacji życia społecznego (Piotrowska 2006: 138). Nie należy jednak wyprowadzać bezpośredniego następstwa dwóch zjawisk, bowiem bardziej współczesnym idei Folkhemmet sposobem urządzania wnętrz był oszczędny funkcjonalizm, rezygnujący ze staromodnych dekoracji i patosu na rzecz jeszcze prostszych i bardziej minimalistycznych rozwiązań, które o wiele lepiej trafiały do powojennego społeczeństwa robotniczego niż gustawiańskie naleciałości w stylu Larssonów. Frykman i Löfgren podkreślają jednak, że Folkhemmet wynikał z ogólnego dziedzictwa oskariańskiego, a artystyczne realizacje Larssonów

19 Alva Myrdal (1912-1986) i Gunnar Myrdal (1898-1987) ekonomiści, politycy i publicyści ważni dla rozwoju szwedzkiego państwa opiekuńczego. Opowiadali się za czynnym wkładem ludzi świata nauki w życie codzienne obywateli poprzez proponowanie konkretnych rozwiązań i modeli. 
były tylko ilustracją obecnych na przełomie XIX i XX wieku przekonań o szczęśliwej rodzinie i bezpiecznym domu jako podstawie dobrego społeczeństwa ${ }^{20}$.

W samym jednak haśle Folkhemmet, tradycyjnie przypisywanym Perowi Albinowi Hanssonowi (Dahlqvist 2002: 445-465), kryje się chyba to, co chciał wykreować Larsson w swoich słonecznych przedstawieniach rodzinnej sielanki w Sundborn. Ogólnie przyjęte polskie tłumaczenie „dom ludu” ogranicza o wiele szersze znaczenie szwedzkiego słowa folk, rozumianego jako naród, ogół społeczeństwa. „Dom ludu” jest zatem miejscem zamieszkania wszystkich, niezależnie od pochodzenia i dochodów, gdzie - jak mówił Hansson podczas słynnego przemówienia w 1925 roku - nie ma ani „pasierbów” ani „beniaminków” (Dahlqvist 2002: 460). Nie tylko wybór słów o charakterze rodzinnym (Szwedzi jako dzieci), ale przede wszystkim sam pomysł Szwecji jako domu był podwaliną dla państwa opiekuńczego, natomiast - jak zaznacza Magdalena Żmuda-Trzebiatowska - włączenie idei folk było istotne dla budowania ponadklasowej wspólnoty wszystkich obywateli (2017: 35).

Naród, ale też lud - te dwa pojęcia były kluczowe dla wspomnianych na początku wywodu dwóch nurtów w sztuce: nationalromantik oraz regionalizmu. Pierwszy widoczny jest w malarskiej twórczości Larssona, przede wszystkim w jego monumentalnych realizacjach dekoracji ściennej Muzeum Narodowego w Sztokholmie (historia sztuki szwedzkiej, wjazd Gustawa Wazy do Sztokholmu), które dowodzą zainteresowania przeszłością, jak również własnej interpretacji historii Szwecji (jak w „Ofierze w przesilenie zimowe”, szw. Midvinterblot). W przestrzeni Lilla Hyttnäs „unarodowiony romantyzm” przejawia się głównie w szacunku dla mebli charakterystycznych dla dawnych czasów, w tym przede wszystkim stylu gustawiańskiego, który powstał w czasach panowania Gustawa III (1746-1792) i został oparty na rokokowych wnętrzach oglądanych na dworze francuskim. Styl ten powrócił w latach 30. i 40. XIX wieku jako inspiracja dla Biedermeieru, lecz potem został całkowicie wyparty przez nowe tendencje (Facos 1998: 64). Larssonowie wzorują się na dawnych rozwiązaniach, odświeżając zabytkowe meble z tego okresu czy inspirując się ich obiciami (ilustracja 5), tym samym przywracają mu dawną świetność i czynią istotnym elementem własnego stylu.

Wielu badaczy kojarzy też twórczość Larssonów z regionalizmem, szczególnie z uwagi na umiejscowienie Sundborn w środkowej Szwecji. Dalarna była przez ówczesną elitę okrzyknięta kolebką tradycji i wartości szwedzkich: „symbolem Szwecji stała się charakterystyczna drewniana chata w kolorze czerwieni faluńskiej" (Żmuda-Trzebiatowska 2017: 29), typowa dla tego regionu. Larssonowie szukali inspiracji w tamtejszej sztuce, ale Carl powtarzał też wzory z Halland i chętnie nawiązywał w swych freskach do motywów z ludowych malowideł w pobliskich kościołach.

20 Autorzy wskazują tu również na twórczość Ellen Key oraz Elsy Beskow, zob. Frykman, Löfgren 2007: 143. 


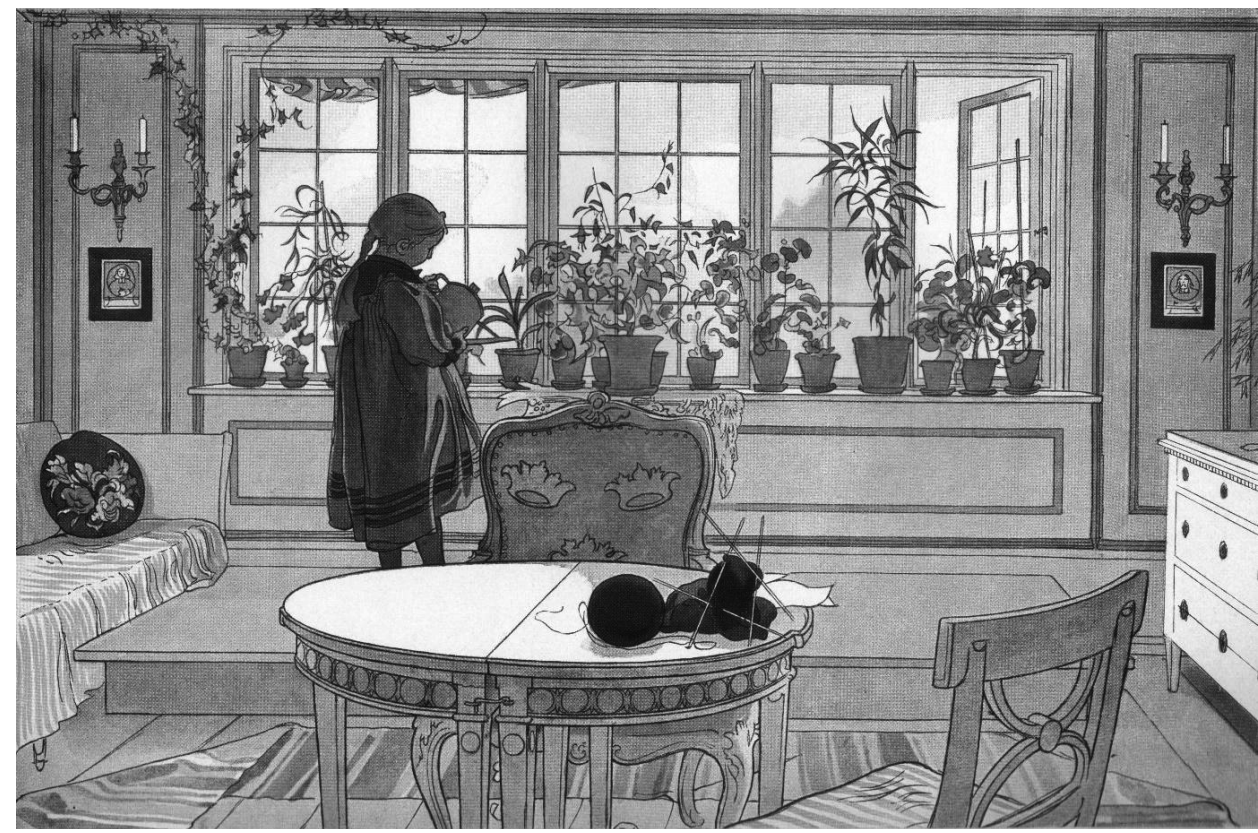

Ilustracja 5. C. Larsson, Ukwiecone okno (szw. Blomsterfönstret), 1894, akwarela na papierze $32 \times 43 \mathrm{~cm}$, Nationalmuseum, Sztokholm

Źródło: https://upload.wikimedia.org/wikipedia/commons/thumb/8/8c/Blomsterf\%C3\% B6nstret_av_Carl_Larsson_1894.jpg/1280px-Blomsterf\%C3\% B6nstret_av_Carl_Larsson_1894.jpg [dostęp: 12.09.2019].

Zainteresowanie tradycjami prowincji i sztuką ludową jest jednak znakiem czasów, praktyką popularną w innych krajach europejskich, poszukujących recepty na „sztukę narodową" wywodzoną z nieskażonej cywilizacją miast wsi. Wielu mieszczan poszukiwało swoich ludowych korzeni, dołączył do nich więc również Carl, który (w przeciwieństwie do swojej żony, która dorastała w Dalarnie), ustanowił nowe miejsce zamieszkania swoją małą ojczyzną.

Być może nazywanie stylu Larssonów szwedzkim stylem narodowym jest zbyt daleko idącym uproszczeniem, lecz Lilla Hyttnäss miała być inspiracją dla Szwedów i ostoją dawno zapomnianych (jak styl gustawiański) czy niedocenianych (sztuka ludowa) pierwiastków istotnych dla budowania szwedzkiej tożsamości. Trzeba jednak podkreślić, że w swojej twórczości oboje inspirowali się także angielskimi wzorcami z ruchu Arts \& Crafts, śledzili postępy Warsztatów Wiedeńskich (Wiener Werkstätte), a także ulegli modzie na japonizm, bez wątpienia mając styczność z drzeworytami japońskimi podczas pobytu w Paryżu. Jak to określił Denis Hagstromer, „jak na ironię coś tak przepełnionego inspiracjami płynącymi 
z obcego wzornictwa stało się nieodłączną częścią szwedzkiej tożsamości kulturowej" (Parissien, red., 2010: 233).

Czy można więc odczytywać realizację posiadłości Lilla Hyttnäs jako zapowiedź Folkhemmet, rodzaj „Szwecji w pigułce”, demokratycznego amalgamatu kultury wysokiej z tradycją ludową? A raczej, które elementy idyllicznego życia w Sundborn mogliby chcieć przejąć twórcy szwedzkiego państwa opiekuńczego? $\mathrm{Z}$ wizualnego punktu widzenia Lilla Hyttnäs nie był idealnym przykładem surowego funkcjonalizmu i typem optymalnego mieszkania, o jakim marzył Szwed lat 60. i 70. XX wieku. Pokrewieństw dzieła Larssonów z dziełem Pera Albina Hanssona i innych polityków szwedzkiej socjaldemokracji należy szukać jednak w samym konstrukcie domu jako miejscu otwartym dla wszystkich, dostosowanego dla każdego obywatela, nowoczesnego, o demokratycznym charakterze, wygodnego i przystępnego.

\section{Idealny styl życia. Larssonowie między IKEA a lagom}

Wnętrza Larssonów stały się także jednym ze źródeł inspiracji dla szeroko pojętego „stylu skandynawskiego", o czym przypomniano podczas retrospektywnych wystaw akwareli Larssona organizowanych w Stanach Zjednoczonych (1982) i Japonii (1994) (Facos 1996: 81). Wiele rozwiązań Larssonów zostało również wprowadzonych na masowy rynek przez szwedzką firmę meblarską IKEA, która na swojej stronie internetowej oficjalnie przyznaje się do inspiracji Larssonami (Our Swedish origins 2010$)^{21}$. „Dom idealny”, reklamowany przez firmę w dystrybuowanych na cały świat katalogach czy pokazowych aranżacjach mieszkania w każdym ze sklepów, jest w gruncie rzeczy tym, czym dom Larssonów jawił się oglądającym albumy na całym świecie. Szwedzka firma zaprojektowała serię produktów wprost zaczerpniętych z pomysłów Carla i Karin, takich jak fotel bujany Lillberg wykonany według projektu Karin (ilustracja 6) czy cała linia mebli Sällskap dedykowanych Larssonom. Zenon Ciesielski wskazywał nawet na regionalizm charakteryzujący ofertę IKEA, mając na myśli przywiązanie Ingvara Kamprada do rodzinnego gospodarstwa Elmtaryd w Smålandii. Twórca IKEA „czerpał pełnymi garściami z tradycji skandynawskich i nordyckich i tak doprowadził do tego, że nazwa IKEA kojarzy się każdemu z bezpretensjonalnym wyposażeniem mieszkania" (Kamprad 1999: 53). Należy dodać, że tę bezpretensjonalność podkreślał już Larsson, lansując dom jako przestrzeń do mieszkania, a nie na pokaz.

${ }^{21}$ Również na polskim fanpage’u IKEA pojawił się wpis dotyczący Larssonów (IKEA [fanpage] 2010). 


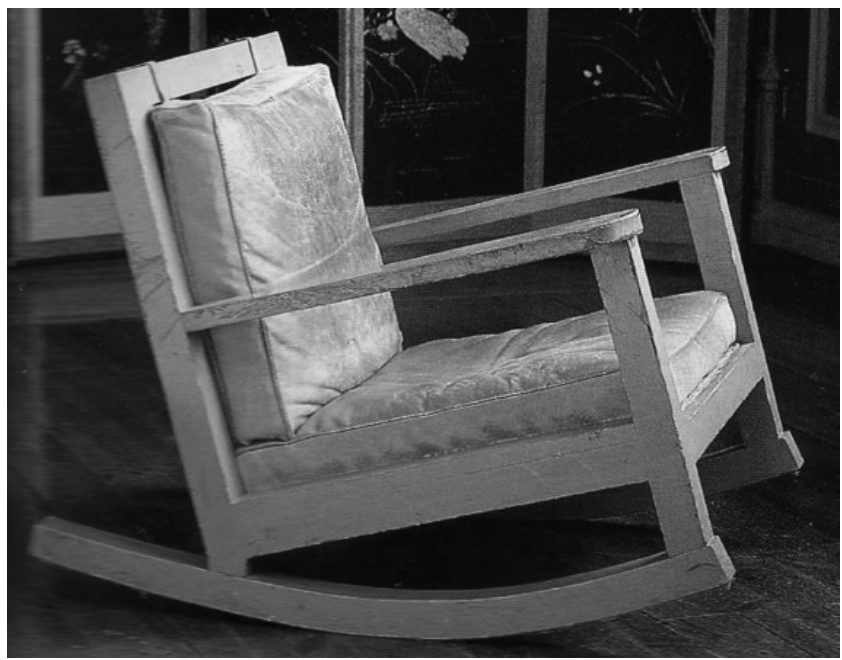

Ilustracja 6. Fotel bujany zaprojektowany przez Karin Larsson

Źródło: https://en.wikipedia.org/wiki/Karin_Berg\%C3\%B6\%C3\%B6_Larsson\#/media/ File:Karin_larsson_schommelstoel.jpg [dostęp: 18.09.2019].

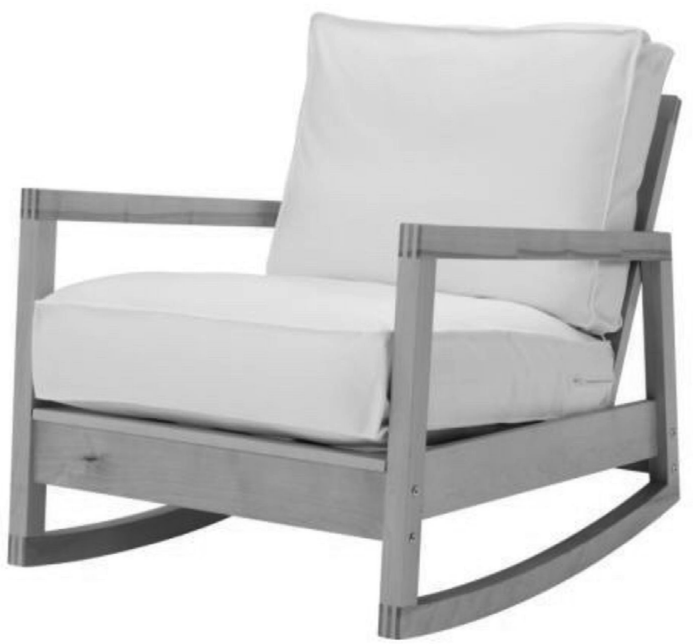

Ilustracja 7. Fotel Lillberg, IKEA

Źródło: ikea.com https://images-na.ssl-images-amazon.com/images/ I/41y9H0GyTOL._SX425_.jpg [dostęp: 12.09.2019]. 
IKEA była pierwszym sklepem, który dawał klientom możliwość zrobienia zakupów z dzieckiem; pociechę można było zostawić w pokoju zabaw i spokojnie oddać się przeglądaniu sklepowej oferty. Co więcej, bardzo dużo uwagi poświęca się projektom dziecięcym: bezpiecznym zabawkom, ergonomicznym mebelkom, odpowiednim tekstyliom. Ilustracje Larssona również podkreślają ważną rolę dzieci. Dom jest ich pełen, co jeszcze u kresu XIX wieku nie było powszechnym zjawiskiem - wcześniej pociechy izolowano w przestrzeni domowej, a pokoje dziecięce były niewielkie i oddalone od salonów czy sypialni rodziców (Frykman, Löfgren 2007: 132). Być może to właśnie obecność roześmianych dzieci stanowiła o sukcesie tak akwareli Larssona, jak i całego obrazu Lilla Hyttnäs. Wiele przemian społecznych wskazywało przecież na to, że nadchodzący XX wiek będzie, jak zakładała Ellen Key, „stuleciem dziecka” (2005).

Zarówno w tekstach samego Carla Larssona, jak i opracowaniach jego twórczości często padają słowa „szczęście”, „szczęśliwy”. Bez wątpienia barwne ilustracje przedstawiające jasne, przytulne wnętrza domu w Sundborn tworzyły obraz domu „idealnego” ze względu na wybór odpowiednich środków. Zilustrowane pomieszczenia są przestronne, wypełnione światłem (naturalnym lub sztucznym), a sportretowani domownicy w skupieniu lub beztrosko oddają się swoim codziennym czynnościom. W ostatnim czasie w wydawnictwach popularnonaukowych często wspomina się lagom, lansowany jako „szwedzki styl życia” (por. Åkeström 2017). Kategoria "nie za dużo, nie za mało, ale w sam raz” miała być szwedzkim odpowiednikiem na odnoszące sukces duńskie hygge. Oba koncepty urosły do rangi „recepty na szczęście” i stały się tematem wielu poradników dotyczących sposobów urządzenia wnętrza, w którym panuje „idealna” atmosfera. Hygge i lagom to dwa różne, trudne do zdefiniowania pojęcia; podczas gdy dla scharakteryzowania pierwszego Włodzimierz Pessel używa hasła słownikowego („hygge - wykreować przyjemną i przytulną atmosferę”22), posłużę się cytatem z publikacji Loli Åkeström: „Lagom nie oznacza nieosiągalnej doskonałości, lecz raczej rozwiązanie optymalne, najbardziej harmonijny sposób, w jaki możemy i powinniśmy działać" (2017). To właśnie w wydawnictwach popularnonaukowych sprowadzono oba zjawiska do tych samych zasad: zrównoważenia, skromności, otaczania się przedmiotami funkcjonalnymi i o wartości emocjonalnej, przeznaczaniem czasu na rekreację, samorealizację, ale również odpoczynek i rodzinę. I gdyby wierzyć, że akwarele Larssona są autentycznym zapiskiem codzienności, można byłoby pokusić się o stwierdzenie, że (oczywiście z tego uproszczonego punktu widzenia) dom Larssonów był czymś w rodzaju archetypu lagom, a może raczej jedną z wielu inspiracji dla współczesnego rozumienia tego pojęcia.

22 W oryginale: „hygge to create a pleasant and cosy atmosphere/ hyggelig - pleasant and cosy", por. Pessel 2018: 35. 


\section{Zakończenie}

Carl i Karin Larsson wnieśli znaczący wkład w wykreowanie „domu idealnego”. Ideał ten może przejawiać się na wielu płaszczyznach i odnosić się do różnych zagadnień. Po pierwsze, i najważniejsze, wnętrze Lilla Hyttnäs stanowiło inspirację dla wielu mieszczańskich domów przełomu XIX i XX wieku, tak w Szwecji, jak i poza jej granicami. Nowatorskie i pomysłowe rozwiązania idące w parze z dekoracyjnością i harmonią były wzorem i przykładem dla wielu pragnących urządzić cztery ściany w sposób zarówno modny, jak i bezpretensjonalny. Co więcej, dom Larssonów stanowił ideał ogniska domowego wypełnionego spokojem i radością, reklamowanym za pomocą albumów wydawanych przez szwedzkiego malarza oraz odwiedzających go dziennikarzy i pisarzy. Sława wyjątkowego genius loci zamieszkującego wnętrza domu znanego artysty przyciągała i przyciąga wielu zwiedzających do miejscowości Sundborn w regione Dalarna. Tym samym atrakcyjność domu i urokliwość barwnych akwareli umacniają pozycję Lilla Hyttnäs jako domu idealnego, czemu przysługują się również tytuły wystaw oraz współczesnych publikacji.

Przekonanie o wyjątkowości domu artystów wywodzi się najprawdopodobniej nie tylko $\mathrm{z}$ tradycji historii sztuki i dużej liczby reprodukcji, która przyczyniła się do znajomości czy przynajmniej wizualnego kojarzenia wspomnianych wnętrz w świadomości przeciętnego Szweda. Lilla Hyttnäs to „dom idealny”, bo stanowi przykład wzorcowego szwedzkiego domu, zarówno pod względem materialnym, jak i ideologicznym. Socjaldemokratyczny Folkhemmet bliski jest koncepcjom prezentowanym przez Larssona we wstępach do jego albumów, nie ma jednak bezpośredniej relacji między tymi zjawiskami, łączy je raczej czerpanie z podobnych idei. Niektóre zagadnienia, takie jak szacunek do przedstawicieli wszystkich warstw społecznych oraz konieczność samorealizacji czy budowanie „szwedzkości” na wielu różnych fundamentach bliskie są obu konstruktom, jednak dużą przesadą byłoby nazwanie Lilla Hyttnäs pierwszym „domem ludu”. Obecny jednak w wyobraźni Szwedów był przypuszczalnie jednym ze źródeł późniejszego sukcesu państwa opiekuńczego. Trudno dzisiaj ocenić, jak do wypowiedzi Pera Albina Hanssona odnieśliby się obywatele pozbawieni oskariańskiego dziedzictwa.

Larssonowie mogą być też kreatorami szwedzkiego stylu rozumianego w bardzo spłyconej formie jako „szwedzki styl życia”, a nawet w uproszczony sposób definiowanego jako lagom. Zawierające się w tej „recepcie na szczęście” pojęcia równowagi, bliskości z naturą czy poszanowania dla czasu wolnego znajdują swoje odbicie $\mathrm{w}$ tzw. skandynawskim sposobie urządzania wnętrz, lansowanym przez firmy meblarskie i media społecznościowe. Estetyczne zdjęcia przedstawiające jasne, przestronne, modnie umeblowane, często pozbawione ludzi lub sprawiające wrażenie „przyłapania” domowników na wykonywaniu ich ulubionych czynności 
przypominają akwarele Larssona w uderzający sposób. Mają one również tę samą funkcję: wykreowania sielskiej atmosfery domu idealnego, w którym dzieciom pozwala się przesiadywać na kuchennym blacie, a psu wylegiwać na dywanie. „Idealność" domu Larssonów zdaje się - stąd w tytule znak zapytania - wyrażać na wielu poziomach, w sposobie dekoracji wnętrz („wnętrze idealne”, czyli takie, które chciałoby się mieć), tworzeniu wyjątkowej atmosfery w miejscu zamieszkania („dom idealny” jako miejsce do życia szczęśliwej rodziny) czy nawet przypisywaniu Szwecji cech „państwa idealnego”, czyli takiego, w którym każdy może czuć się jak u siebie.

\section{Bibliografia}

Åkerström, L. (2017). Szwedzki sekret dobrego życia. Lagom. Tłum. N. Mętrak-Ruda. Warszawa: Marginesy.

Beltramelli, A. (1907). La Casa Gioconda - Una visita a Carl Larsson. Corriere della Sera. 13.09. Ciesielski, Z. (2016). Dzieje kultury skandynawskiej. T. 1-2. Gdańsk: Marpress.

Costaras, N., Manoli, T. (1997). Preparations for „Carl and Karin Larsson: Creators of the Swedish Style". Conservation Journal 25. London: Victoria and Albert Museum, http://www.vam. ac.uk/content/journals/conservation-journal/issue-25/preparations-for-carl-and-karinlarsson-creators-of-the-swedish-style/ [dostęp: 7.07.2016].

Dahlqvist, H. (2002). Folkhemsbegreppet: Rudolf Kjellén vs Per Albin Hansson. Historisk Tidskrift 3.

Facos, M. (1996). The Ideal Swedish Home W: Ch. Read (ed.). Not at Home. The Suppression of Domesticity in Modern Art and Architecture. London: Thames \& Hudson.

Facos, M. (1998). Rootedness. W: Tejże. Nationalism and the Nordic Imagination. Swedish Art of the 1890s. California: University of California Press.

Facos, M. (2011). Ett hem och socialdemokratin. W: Carl Larsson - Drömmar om harmoni. 16.09.2011-8.01.2012. Helsinki: Åbo Konstmuseum.

Frykman, J., Löfgren, O. (2007). Narodziny człowieka kulturalnego. Kształtowanie się klasy średniej w Szwecji XIX i XX wieku. Tłum. G. Sokół. Kęty: Wydawnictwo Marek Derewiecki.

Gedin, P. (2011). Jag. Carl Larsson. En biografi av Per I. Gedin. Stockholm: Bonniers.

IKEA [fanpage]. (2010), https://www.facebook.com/IKEApl/posts/126892944016833 [dostęp: 12.09.2019].

Kamprad, I. (1999). Historia IKEA. Ingvar Kamprad rozmawia z Bertilem Torekullem. Tłum. T. Manicki. Warszawa: Vik.

Kent, N. (1922). The Triumph of Light and Nature. Nordic Art 1740-1940. London: Thames and Hudson.

Key, E. (2005). Stulecie dziecka. Tłum. I. Moszczeńska. Warszawa: Wydawnictwo Akademickie „Żak”.

Kopczyński, W. (2013). Oskariańskie dziedzictwo. Pojawienie się terminu „Hembygd”. Zwierciadło Etnologiczne. Rocznik Katedry Etnologii i Antropologii Kulturowej Uniwersytetu Szczecińskiego 2.

Larsson, C. (1998). Ett Hem. 24 målningar af Carl Larsson. Stockholm: Bra Böcler.

Słownik języka polskiego (1978). T. 1. H. Szkiłądź, S. Bik, C. Szkiłądź (red.). Warszawa: PWN. 
Our Swedish Origins. (2010). IKEA, www.ikea.com/ms/en_GB/about_ikea/the_ikea_way/swedish_heritage/ [dostęp: 9.07.2016].

Parissien, S. (red.). (2010). Historia wnętrz. Dom od roku 1700. Tłum. E. Gorządek. Warszawa: Wydawnictwo „Arkady”.

Pessel, W. (2018). The Hygge Phenomenon. Between a Lifestyle and Nationalism. Przeglad Humanistyczny 2.

Piotrowska, E. (2006). Dzieje myśli szwedzkiej XX wieku. Od narodowego konserwatyzmu do globalizmu. Poznań: Wydawnictwo Naukowe Uniwersytetu im. Adama Mickiewicza.

Puvogel, R. (1994). Carl Larsson. 1853-1919. Akwarele i rysunki. Tłum. E. Tomczyk. Kolonia: Taschen.

Udsen, V. (ed.). (2000). Carl Larsson-Gården. W: Tegoż. Living Museums in Scandinavia, Copenhagen.

Varnedoe, K. (1988). Carl Larsson. W: Tegoż. Northern Light. Nordic Art at the Turn of the Century. New Haven \& London: Yale University Press.

Wisiecka, M. (2015). Fotografik polski Jan Malisz o Carlu Larssonie. Biuletyn Biblioteki Jagiellońskiej LXV.

Żmuda-Trzebiatowska, M. (2017). Folkhemmet - czyli wspólny, dobry dom - w szwedzkich narracjach literackich o dzieciństwie. Poznań: Wydawnictwo Naukowe Uniwersytetu im. Adama Mickiewicza. 